\title{
Comparative Evaluation of the Antimicrobial Efficacy of Different Irrigating Solutions on Endodontic Pathogens - An In Vivo Study
}

\author{
Suneeth Shetty ${ }^{1}$, Sunil Tejaswi², Ambikathanya U.K. ${ }^{3}$, Akanksha Mittal ${ }^{4}$ \\ 1, 2, 3,4 Department of Conservative Dentistry \& Endodontics, J.S.S Dental College \& Hospital, \\ J.S.S Academy of Higher Education \& Research (JSSAHER), Mysore, Karnataka, India.
}

\section{ABSTRACT}

\section{BACKGROUND}

The key to a successful endodontic treatment is to ensure complete eradication of the infection present and to prevent reinfection. This depends on meticulous disinfection using intracanal irrigants. In dentistry the most commonly used irrigant is sodium hypochlorite which has the disadvantages of cytotoxicity and unpleasant taste. The extracts of neem have been used since ages for their medicinal values and used widely for health care. However, the potential use of such an agent for the success of endodontic procedures has not yet been investigated. Hence, if proved effective, such a natural agent will have a dominant hold against the chemical disinfectants in terms of biocompatibility and tissue response. This study aimed to evaluate the effectiveness of Q-MIX (2 in 1), $10 \%$ neem (Azadirachta indica), and $2 \%$ sodium hypochlorite on the growth and culture of Enterococcus faecalis and Mutant Streptococcus over a period of 4 weeks.

\section{METHODS}

This is a descriptive study conducted among samples collected from 30 healthy patients who were indicated for pulpectomy. The sample size was taken for convenience. Incisors of these individuals were selected on the basis that they had to undergo endodontic treatment due to primary endodontic infection. The zones of inhibition were measured by agar well diffusion method. Statistical analysis was done using independent T test \& chi-square test.

\section{RESULTS}

Statistical analysis showed that the mean zones of inhibition in this study were 20.54 $\mathrm{mm}, 9.65 \mathrm{~mm}$ and $4.54 \mathrm{~mm}$ for Q-MIX (2 in 1), $10 \%$ neem and $2 \%$ sodium hypochlorite. The significance was greater between Q-MIX (2 in 1) and the other two agents as the $\mathrm{P}$-value was $<0.001$.

\section{CONCLUSIONS}

The result indicated Q-MIX (2 in 1) is a more effective root canal irrigant when compared to $10 \%$ neem and $2 \%$ sodium hypochlorite.

\section{KEY WORDS}

Q-MIX (2 in 1), Azadirachta indica, Apical Periodontitis, Enterococcus faecalis
Corresponding Author: Dr. Suneeth Shetty, Department of Conservative Dentistry \& Endodontics, J.S.S Dental college \& Hospital, J.S.S Academy of Higher Education \& Research (JSSAHER), Mysore, Karnataka, India.

E-mail: s_suneeth@yahoo.com

DOI: 10.14260/jemds/2021/169

How to Cite This Article:

Shetty S, Tejaswi S, Ambikathanya UK, et al. Comparative evaluation of the antimicrobial efficacy of different irrigating solutions on endodontic pathogens - an in vivo study. J Evolution Med Dent Sci 2021;10(11):789-792, DOI: 10.14260/jemds/2021/169

Submission 21-10-2020, Peer Review 21-01-2021, Acceptance 27-01-2021, Published 15-03-2021.

Copyright (C) 2021 Suneeth Shetty et al. This is an open access article distributed under Creative Commons Attribution License [Attribution 4.0 International (CC BY 4.0)] 


\section{BACKGROUND}

Endodontic infections are polymicrobial in nature and pose a serious threat to the success of endodontic treatment. Complete intracanal and microbial disinfection has to be done before the three-dimensional obturation for a successful treatment. The key to a successful endodontic treatment is to ensure complete eradication of the infection present in the root canal system with its ramifications and prevention of re infection in the future. This can be achieved by completion of the endodontic triad which involves cleaning \& shaping, microbial control and three dimensional obturation of the canal space.1,2 The literature suggests that persistent intraradicular infection may be the major cause of failure of root canal treatment. The chances of a favourable outcome are significantly higher if the infection is eliminated completely before the root canal system is obturated. ${ }^{3}$

However, total elimination of bacteria is difficult to accomplish in spite of complete chemo mechanical preparation. The microorganisms frequently detected in pulp include; E. faecalis, S. mutants, S. aureus, L. acidophilus, F. nucleatum and $C$. albicans. In dentistry enterococcus species in particular have been found to be associated with chronic periodontitis \& failed root canal treatments involving chronic apical periodontitis. ${ }^{4}$ To eliminate these microorganisms, the role of the irrigant plays a critical role along with cleaning and shaping. New literature has shown that various natural products have proven to be effective in dental treatment. Sodium hypochlorite the most commonly used root canal irrigant is known for its tissue dissolving and antimicrobial activity. Its disadvantages include cytotoxicity, unpleasant taste and its inability to remove the smear layer. Neem leaves have a broad antimicrobial action and have been used since ages for their medicinal values and used widely for health care.5,6 However, the potential use of such agents for the success of endodontic procedures have yet to be investigated. Hence, if proved effective, such natural agents will have dominant hold against the chemical disinfectants presently used, in terms of biocompatibility and tissue response.7,8

\section{Objectives}

This study aims to evaluate the effectiveness, Q-MIX (2 in 1) 10 $\%$ neem and $2 \%$ sodium hypochlorite on the growth and culture of E. faecalis and M. streptococcus over a period of 4 weeks.

\section{METHODS}

The present study was a clinical experimental randomised study conducted in the Department of Conservative Dentistry \& Endodontics, J.S.S Dental College Mysore, India from May 2018 to July 2018. All the patients were informed about irrigant protocol that was going to be followed and after obtaining written consent the treatment was started. 30 patients in the age group of 18 - 40 years were selected for the study. The samples were collected from 30 healthy patients that who were indicated for pulpectomy and taken for convenience. Sample size was taken based on the conveniences of the study. The microbiological procedure was done in the Department Microbiology, J.S.S College and Hospital, Mysore using preparation of $10 \%$ neem extract.

\section{Extraction Method}

- Azadirachta indica leaves were dried at $50^{\circ} \mathrm{C}$ and powdered using an electric blender.

$30 \mathrm{~g}$ of the powder was packed in a double pouch made of Whatman filter paper \# 1 and placed in thimble of Soxhlet extractor. $300 \mathrm{ml}$ of ultrapure water with resistivity 18.1 mega ohms was used for refluxing at temperature of $100^{\circ}$ $\mathrm{C}$ (since water was used as solvent, taking its boiling point into account).

- The reflux process was carried out until all phytocompounds eluted into the solvent i.e., water.

- Azadirachta indica extract gave a deep green color extract.

- The extract was rotary evaporated to remove the excess liquid and further dried in hot air oven at $50^{\circ} \mathrm{C}$ to get extract powders which were stored at $4^{\circ} \mathrm{C}$ until further use.

- $\quad$ The extract powders were $10 \%$ (as we used $30 \mathrm{~g}$ in 300 $\mathrm{ml}$ for Soxhlet extraction).

\section{In Vitro Bacteriological Examination}

- Bacteriological examination was carried out on pure cultures of $S$. mutans (MTCC 497) and E. faecalis (MTCC 439). Pure cultures for the present work was obtained from microbial type cell culture and gene banking (MTCC) Chandigarh, India.

- $\quad$ S. mutans was subcultured in brain-heart infusion (BHI) broth and E. faecalis in Luria broth.

- The optical density (OD) of the inoculum was adjusted to $10^{6} \mathrm{CFU} / \mathrm{mL}$ using ultraviolet-visible (UV-Vis) spectrophotometer with the standard 0.5 MacFarland.

- $\quad$ BHI agar and Trypticase Soy Agar (TSA) plates were prepared.

- $\quad 20 \mu \mathrm{L}$ of inoculum was spread on agar surface using sterile L-rod (all procedures carried out under aseptic precaution in laminar air flow chamber).

- 4 wells were scored on the surface of agar with sterile cork-borer and the wells were filled till their brim with respective serial diluted extract.

- $\quad$ The plates incubated at $37^{\circ} \mathrm{C}$ were inspected after $24 \mathrm{hrs}$. for growth or inhibition.

- The minimum inhibitory concentration for the extracts was found to be $10 \%$

\section{Selection Criteria}

- Upper central incisors without any fracture (vertical or horizontal)

- No non-carious lesion and in periodontally sound condition.

- Endodontic treatment due to primary endodontic infection.

- Periapical lesion not bigger than $2 \mathrm{~mm}$ in diameter

- Pre-operative radiographs were taken to confirm the periapical lesion. 
- Access cavity preparation was done under rubber dam isolation and a 25 barb broach was used to extirpate the pulp tissue.

Working length was measured by placing a $25 \mathrm{k}$ file till the apex and minus $1 \mathrm{~mm}$. Confirmatory intraoral periapical radiograph (IOPAR) was taken. Irrigation was done using a side vented needle with $5 \mathrm{ml}$ of the Neem / Q-MIX / NaOCl. 25 size paper points were then placed in the access cavity for 1min duration 4 times, collected and sent for microbiological analysis against $E$. faecalis and M. streptococcus. This protocol was followed for a 4-week period. No cleaning and shaping was done during the study period as we wanted to observe the action of the irrigants on the microorganisms after each week for a period of 4 weeks.

\section{Microbial Analysis}

- Patient samples were collected from the root canals of anterior teeth. Sterile paper points of size (25) were used to collect the samples from root canal (RC) prior to irrigation and post-irrigation with the extract, Q MIX and $2 \%$ sodium hypochlorite.

- $\quad$ The collected samples were immediately transferred to sterile Eppendorf's tubes containing DMEM (Dulbecco's Modified Eagles Medium) to transport to the laboratory.

- In laboratory, the paper points were retrieved from transport medium. The paper points were washed thrice with $1 \mathrm{X}$ phosphate-buffered saline (PBS) using micropipette (1 ml PBS was used to wash each paper point. The paper points were placed inside the measured amount of PBS in a $2 \mathrm{ml}$ capacity Eppendorf tubes and vortexed for 2 - 3 min to loosen the biofilm containing bacteria attached to paper points).

- The experiment was performed in triplicates to confirm the uniform distribution of biofilm within PBS.

- $20 \mu \mathrm{L}$ of clinical samples were spread on to the surface of BHI agar or TSA agar using sterile L-rod and plates were incubated at $37^{\circ} \mathrm{C}$ for $24-48 \mathrm{hrs}$.

- After incubation period, the plates were checked for colony formation. The bacterial colonies were counted using manual colony counter (vision microsystems) (exclusion less than 30 and more than 300).

\section{Statistical Analysis}

Observations from the microbial procedure were made and results were statistically analysed and tabulated. Statistical analysis was done using independent $\mathrm{T}$ test \& chi-Square test. All the statistical methods were carried out using Statistical Package for the Social Sciences (SPSS) software (20.0). Mean and standard deviation of the zones of inhibition were produced by repeated analysis of variance.

\section{RESULTS}

Results were statically analysed using independent T tests \& chi Square test. All the statistical methods were carried out with SPSS Software. (20.0). A statistically significant difference existed over the observation period of 4 weeks with Q-MIX (2 in 1), neem, with significant reduction of the number of colonyforming units after each week.

\begin{tabular}{|c|c|c|c|c|c|}
\hline Irrigants & $\begin{array}{c}\text { First } \\
\text { Week }\end{array}$ & $\begin{array}{c}\text { Second } \\
\text { Week }\end{array}$ & $\begin{array}{c}\text { Mean } \\
\text { Difference }\end{array}$ & t-Value & P-Value \\
\hline Neem & $49.50(5.28)$ & 23.60 & 26.900 & 13.248 & $\mathrm{P}<0.001$ \\
\hline Q-mix & $\begin{array}{l}143.40 \\
(9.571)\end{array}$ & $\begin{array}{l}128.50 \\
(8.10)\end{array}$ & 14.900 & 6.266 & $\mathrm{P}<0.001$ \\
\hline $\begin{array}{c}\text { Sodium } \\
\text { hypochlorite }\end{array}$ & $\begin{array}{c}79.20 \\
(11.58)\end{array}$ & $\begin{array}{c}70.60 \\
(12.97)\end{array}$ & 8.600 & 6.566 & $\mathrm{P}<0.001$ \\
\hline
\end{tabular}

\begin{tabular}{|cccccc|}
\hline Irrigants & $\begin{array}{c}\text { First } \\
\text { Week }\end{array}$ & $\begin{array}{c}\text { Second } \\
\text { Week }\end{array}$ & $\begin{array}{c}\text { Mean } \\
\text { Difference }\end{array}$ & t-Value & P-Value \\
Neem & $20.50(5.28)$ & $13.60(5.85)$ & 7.900 & 13.248 & $\mathrm{P}<0.001$ \\
Q-mix & 143.40 & 128.50 & 14.900 & 6.266 & $\mathrm{P}<0.001$ \\
Sodium & $(9.571)$ & $(8.10)$ & & & \\
hypochlorite & $\begin{array}{c}79.20 \\
(11.58)\end{array}$ & $\begin{array}{c}70.60 \\
(12.97)\end{array}$ & 8.600 & 6.566 & $\mathrm{P}<0.001$ \\
\hline \multicolumn{7}{|c|}{ Table 2. S. mutants between First and Second Week } \\
\hline
\end{tabular}

\begin{tabular}{|cccccc|}
\hline Irrigants & First Week & $\begin{array}{c}\text { Third } \\
\text { Week }\end{array}$ & $\begin{array}{c}\text { Mean } \\
\text { Difference }\end{array}$ & t-Value & P-Value \\
Neem & $24.10(8.76)$ & $2.70(2.00)$ & 4.40 & 14.482 & $\mathrm{P}<0.001$ \\
Q-mix & $52.00(10.41)$ & $\begin{array}{c}44.70 \\
(8.62)\end{array}$ & 7.30 & 4.245 & 0.002 \\
$\begin{array}{c}\text { Sodium } \\
\text { hypochlorite }\end{array}$ & $44.50(8.01)$ & $33.2(8.66)$ & 11.30 & 2.905 & 0.017 \\
\hline \multicolumn{5}{|c}{ Table 3. E faecalis between First and Third Week } \\
\hline \multicolumn{5}{c}{} \\
\hline \multicolumn{5}{c}{}
\end{tabular}

\begin{tabular}{|cccccc|}
\hline Irrigants & $\begin{array}{c}\text { First } \\
\text { Week }\end{array}$ & $\begin{array}{c}\text { Third } \\
\text { Week }\end{array}$ & $\begin{array}{c}\text { Mean } \\
\text { Difference }\end{array}$ & t-Value & P-Value \\
Neem & $\begin{array}{c}29.50 \\
(5.27)\end{array}$ & $10.50(3.10)$ & 4.900 & 28.502 & $\mathrm{P}<0.001$ \\
Q-mix & $\begin{array}{c}143.40 \\
(9.57)\end{array}$ & $125.80(7.66)$ & 17.60 & 5.992 & $\mathrm{P}<0.001$ \\
$\begin{array}{c}\text { Sodium } \\
\text { hypochlorite }\end{array}$ & $\begin{array}{c}79.20 \\
(11.58)\end{array}$ & $70.70(13.47)$ & 8.50 & 7.005 & $\mathrm{P}<0.001$ \\
\hline \multicolumn{6}{|c|}{ Table 4.S. mutant between First and Third Week } \\
\hline
\end{tabular}

\begin{tabular}{|cc|}
\hline Q Mix 2 in 1 & Dentsply \\
25 no barb broach & Mani \\
25 no k file & Mani \\
25 no paper points & Dentsply \\
25 no k file & Dentsply \\
$2 \% \mathrm{NaOCl}$ & Vishal Dentocare \\
Rubber dam & Hygienic \\
\hline Table 5. Materials Used for the Present Study \\
\hline
\end{tabular}

\section{DISCUSSION}

Endodontic treatment is essentially directed towards the prevention and control of pulpal and periradicular infections. However, total elimination of bacteria is difficult to accomplish in spite of complete chemo-mechanical preparation. Irrigants play a critical role in this entire procedure. Irrigants used saline, sodium hypochlorite, hydrogen peroxide (H202), chlorhexidine (CHX), mixture of tetracycline, acid and detergent (MTAD) etc.

The neem plant, Azadirachta indica is a member of the Mahogany family Melacace and grows in tropical and subtropical regions, but is currently grown in many parts of the world. Neem leaves have shown antimicrobial action against $E$. faecalis and $S$. mutants. The microorganisms frequently detected in pulpal infections which are fresh, and reinfection include E. faecalis, $S$. mutants, $S$. aureus, $L$. acidophilus, F. nucleatum and C. albicans. To eliminate the 
microorganisms, the irrigants used in endodontics should have antiseptic effects, be bacteriostatic, bacteriocidal and biocompatible with minimal periradicular tissue effect.7,9

In dentistry, enterococcus species, in particular Enterococcus Faecalis, have been found to be associated with chronic periodontitis and failed root canal treatments involving chronic apical periodontitis. Medicinal plants have the potential to be used as source of safe irrigants but require a lot research and in vivo studies.

Q-MIX was introduced in 2011 and considered as a novel irrigant for smear layer removal with added antimicrobial agents. It contains ethylenediaminetetraacetic acid (EDTA), chlorhexidine (CHX) and a detergent (cetrimide). ${ }^{10}$

The principle of adding a surfactant agent is to lower the surface tension of solution and increase its wettability and consequently enhance the flow of the irrigating solution into the root canal and its contact with smear layer and the underlying dentin. ${ }^{11}$ It has demonstrated bactericidal property against $E$. faecalis in less time. It also completely removes the smear layer and smear plugs. It enhances the disinfection and demineralisation of radicular dentin due to the chelating effect of EDTA.12,13,14

\section{CONCLUSIONS}

Both Q-MIX and neem caused significant reduction in the number of colony-forming units post irrigation after each week which was statistically significant. Q-MIX (2 in 1) is a more effective root canal irrigant when compared to $10 \%$ neem and $2 \%$ sodium hypochlorite.

Data sharing statement provided by the authors is available with the full text of this article at jemds.com.

Financial or other competing interests: None.

Disclosure forms provided by the authors are available with the full text of this article at jemds.com.

\section{REFERENCES}

[1] Abraham S, Raj JD, Venugopal M. Endodontic irrigants: a comprehensive review. J Pharm Sci Res 2015;7(1):5-9.
[2] Hajifattahi F, Moravej-Salehi E, Taheri M, et al. Antibacterial effect of hydoalcholic extract of punica granatum linn. Petal on common oral microorganisms. International Journal of Biomaterials 2016;2016:1-6.

[3] Palombo EA. Traditional medicinal extracts and natural products and activity against oral bacteria: potential application in the prevention and treatment of oral diseases. Evidence-Based Complementary and Alternative Medicine 2011;2011:1-15.

[4] Divyashree P, Ravi K, Punica granatum: a review on it's potential role in treating periodontal disease. J Indian Soc Periodontol 2014;18(4):428-32.

[5] Wang QQ, Zhang $\mathrm{CF}$, Chu $\mathrm{CH}$, et al. Prevalence of enterococcus faecalis; its role in root canal treated teeth with apical perodontics. Int J Oral Sci 2012;4(1):19-23.

[6] Stuart CH, Schwartz SA, Beeson TJ, et al. Enterococcus fecalis: it's role in root canal treatment failure and current concepts in retreatment. J Endod 2006;32(2):93-8.

[7] Anusha R. Herbal products in oral hygiene maintainence a review. Journal of Pharmacy 2015;5(1):48-51.

[8] Ambareen Z, Konde S, Raj N, et al. Antimicrobial efficacy of herbal extracts. International Journal of Oral Health Dentistry 2015;1(3):108-13.

[9] De Souza Vasconcelos LC, Sampiao FC, Sampaio MCC, et al. Minimum inhibitory concentration of adherence of Punica granatum Linn (pomergrnate) gel against $\mathrm{S}$. mutants, S. mitis and C. albicans. Braz Dent J 2006;17(3):223-7.

[10] Dai L, Khechen K, Khan S, et al. The effect of QMIX, an experimental antibacterial root canal irrigant, on removal of canal wall smear layer and debris. J Endod 2011;37(1):80-4.

[11] Scott MB, Zilinski GS, Kirikpatrick TC, et al. The effects of irrigants on the survival of human stem cells of the apical papilla, including endocyn. J Endod 2018;44(2):263-8.

[12] Tewari Rk, Kapoor b, Mishra SK, et al. Role of herbs in endodontics. J Oral Res Rev 2016;8(2):95-9.

[13] Alharbi A, Aliuddin S, Alharbi TA, et al. Herbal endodontic irrigants. Int J Prev Clin Dent Res 2017;4(4):311-4.

[14] Tay CX, Quah SY, Lui JN, et al. Matrix metalloproteinase inhibitor as an antimicrobial agent to eradicate enterococcus faecalis biofilm. J Endod 2015;41(6):85863. 